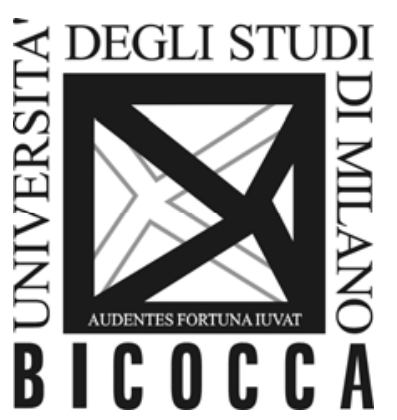

DEPARTMENT OF ECONOMICS,
MANAGEMENT AND STATISTICS
UNIVERSITY OF MILAN - BICOCCA

DEMS WORKING PAPER SERIES

\title{
FDI and Heterogeneous Performance of European Enterprises
}

Valeria Gattai, Giorgia Sali

No. 291 - February 2015

Dipartimento di Economia, Metodi Quantitativi e Strategie di Impresa Università degli Studi di Milano - Bicocca

http://dems.unimib.it/ 


\title{
FDI and Heterogeneous Performance of European Enterprises
}

\author{
Valeria Gattai $^{*}$ and Giorgia Sali ${ }^{\bullet}$
}

\begin{abstract}
This paper investigates the link between internationalization and performance in Europe. It takes a microeconomic perspective and studies how Foreign Direct Investment (FDI) experience relates with European firms' economic, innovation and financial performance. Drawing on a large longitudinal database, our multinomial logit estimates suggest that FDI really matters. Indeed, firms experiencing some FDI (either inward, outward or both) enjoy a superior performance compared with purely domestic enterprises. Moreover, within the class of FDI players, firms engaged in inward and outward FDI turn out to be better than those engaged only in outward FDI, which are better than those engaged only in inward FDI. These results are robust to several performance measures and alternative specifications including firm, industry and country controls.
\end{abstract}

JEL: F23, L25, O52

Keywords: FDI, Heterogeneous firms, Europe

\footnotetext{
* Corresponding author, Università di Milano-Bicocca, DEMS, Piazza Ateneo Nuovo 1, 20126 Milan (Italy), Tel: +39 0264483224, Fax: +39 0264483085, Email address: valeria.gattai@unimib.it - Università di Milano-Bicocca, Piazza Ateneo Nuovo 1, 20126 Milan (Italy).
} 


\section{Introduction}

The last several decades have documented a notable increase in firms' commitment to foreign markets, drawing researchers' attention to the characteristics of international versus domestic enterprises.

Starting from the seminal contribution of Bernard and Jensen (1995), many scholars around the world have begun to investigate the relationship between internationalization and performance at the microeconomic level. They suggest that globally engaged enterprises tend to be a minority, compared with purely domestic players, but they perform better on a number of economic indicators (for recent surveys, see: Lopez 2005; Wagner 2007, 2012; Greenaway and Kneller 2007; Singh 2010; Hayakawa et al. 2012).

Two alternative although not mutually exclusive hypotheses explain why firms engaged in international activities could outperform domestic enterprises. The first hypothesis, called selfselection, suggests that causality runs from performance to internationalization. In the spirit of Melitz (2003), there are ex ante performance differences between firms that will become international and firms that will keep serving the domestic market. This is because operating abroad involves additional costs related to transportation, marketing, human capital and production that provide a natural entry barrier to less successful firms. The second hypothesis, called learning-by-internationalization, postulates that causality runs the other way around, from internationalization to performance. In this sense, ex post performance differences result from firms' exposure to the international arena, through interaction with foreign competitors and customers that encourages reducing costs, quality rising processes and R\&D investment.

Despite the causality direction ${ }^{1}$, the existence of a positive and systematic correlation between internationalization and performance is one of the most striking regularities of the new millennium. Impressively, it holds irrespective of the year and the country of the analysis, and it is robust to several measures of internationalization and performance indicators.

While the first contributions mostly drew on US data, large longitudinal datasets have recently become available in Europe as well, triggering new academic research on the topic. Enough evidence has been accumulated over time from Germany (Vogel and Wagner 2010; Vogel 2011), Belgium (Pisu 2008; Muuls and Pisu 2009), France (Eaton et al. 2004; Temouri et al. 2013), Portugal (Siva et al. 2010a, b), Italy (Castellani et al. 2010, Serti et al. 2010), Ireland (Ruane and Sutherland 2005; Lawless 2009), Slovenia (Damijan and Kostevc 2006; De Loecker 2007), Russia (Wilhelmsson and Kozlov 2007), Spain (Manez-Castillejo et al. 2010; Esteve-Perez et al. 2013), Sweden (Andersson et al. 2008; Eliasson et al. 2009), Netherlands (Kox and Rojas-Romagosa 2010), UK (Breinlich and

\footnotetext{
${ }^{1}$ This is still an open issue from an empirical point of view. See Wagner (2012) and Hayakawa et al. (2012) on this point.
} 
Criscuolo 2011; Gorg and Spaliara 2014), Denmark (Eriksson et al. 2009), Hungary (Bekes et al. 2011; Altomonte and Bekes 2010) ${ }^{2}$ etc. to derive a neat and consistent portrait of European firms that trade. For instance, there exists a strong correlation between trade and productivity, with importers and exporters being more productive than purely domestic firms. Adding to this, the number and type of destinations of export and origins of import matter and evidence is in favour of self-selection rather than learning-by-internationalization. Furthermore, when trade and Foreign Direct Investment (FDI) are compared, the productivity ranking among firms with different international experience has FDI makers at the top, traders in the middle and domestic firms at the bottom of the distribution.

Despite the large body of evidence that has accumulated over time, we believe a couple of gaps still wait to be filled. For instance, the definition of "internationalization" tend to be quite narrow: while there are dozens of papers on trade, evidence on FDI in Europe is rather scant. Moreover, we are not aware of any single study considering the joint effect of inward and outward FDI in a unitary framework. Another gap, in the authors' view, pertains the choice of performance measures that rarely include economic, innovation and financial variables, adding to labour and total factor productivity. Lastly, even though single country analysis are quite numerous in Europe, only a few papers take a cross-country perspective to deal with the internationalization-performance nexus (see, for instance: ISGEP 2008; Mayer and Ottaviano 2008; Barba Navaretti et al. 2011, 2012; Temouri et al. 2013; Haller et al.2014). Still, to the best of our knowledge, existing cross-country studies typically consider a subset of European countries, which narrows down the scope for comparability and generalizability of results.

This paper asks whether FDI matters in explaining the link between internationalization and performance in Europe.

In light of the above discussion, we hazard three main departures from the existing literature. First, when defining "internationalization", we focus on the relatively unexplored case of FDI, rather than trade. To account for all possible effects of foreign direct investment on performance, we build an original taxonomy of FDI combining inward and outward operations in a unitary framework. Our underlying assumption is that both inward and outward FDI might matter for performance through a mixture of spillover effects, self-selection and/or learning by internationalization ${ }^{3}$. Second, when measuring "performance", we do not restrict attention to productivity, but rather open the floor to other economic, innovation and financial variables that might be correlated with firms' experience in

\footnotetext{
${ }^{2}$ Please, note that this reference list if far from being complete, it simply provides a few examples of papers using European data. While reviewing the related literature goes beyond the goal of the present paper, the reader is referred to Lopez (2005), Wagner (2007, 2012), Greenaway and Kneller (2007), Singh (2010) and Hayakawa et al. (2012) for excellent surveys on the topic.

${ }^{3}$ For a survey on direct and indirect effects of inward FDI, see Castellani (2006). The effect of outward FDI on performance are instead reviewed in Greenaway and Kneller (2007).
} 
foreign direct investment. Third, we employ quite a large longitudinal dataset that covers Europe as a whole, to exploit country- adding to industry- and firm-level heterogeneity. Our data, downloaded in 2014, rely on the global company database Orbis and include more than 12000 firms. We are not aware of any previous study on the topic drawing on the same data.

Our descriptive statistics document that FDI experience is quite notable throughout Europe, involving the majority of the sampled firms. Multinomial logit estimates further suggest that foreign direct investment matters to interpret heterogeneity in performance among European enterprises. As the most notable finding of our econometric exercise, firms with some FDI experience enjoy a better performance compared with purely domestic ones. Furthermore, within the class of FDI players, firms engaged in inward and outward operations are better than those engaged only in outward FDI, which are better than those engaged only in inward FDI. This ranking is robust to several measures of performance and alternative specifications including firm, industry and country controls.

The remainder of the paper is structured as follows. Section 2 offers a brief data description and some basic information on our sample. Section 3 introduces our taxonomy of FDI and provides some descriptive statistics. Section 4 is completely devoted to the econometric analysis, with comments on the specification, the empirical model, the variables and the main results. Section 5 then concludes and sets forth future lines of research.

\section{Data}

For the purpose of the present research, we employ firm-level information relying on the global company database Orbis. Orbis provides balance sheet details on enterprises worldwide, including economic, innovation and financial data. Moreover, it displays detailed information about the firm's ownership structure, providing the complete list of its shareholders and subsidiaries. For the sake of completeness, it should be mentioned that economic, innovation and financial data cover a long period allowing researchers to access not only current but also past information. On the contrary, data concerning the ownership structure are available only for the last year. This provides some constraints to the empirical analysis preventing, for instance, from using panel techniques.

Our database covers the whole set of industrial companies listed on the stock market and located in Europe. Industrial companies are selected out of a long list of company types, including: banks, insurance companies, financial companies, private equity funds, venture capital, hedge funds, mutual and pension funds, foundation and research institutes and public authorities. Given the wide range of company types available in Orbis, we believe focusing on industrial firms is important to study the behaviour of heterogeneous actors within a relatively homogeneous class, which still covers all US SIC 2-digit sectors. Moreover, even though Orbis collects information on both listed and unlisted 
companies, we restrict attention to the former. This is because listed firms are surveyed with a more detailed format, which is more appropriate for our goals. Lastly, our definition of Europe actually corresponds to the European Union (EU), and all 28-member states are considered. The EU is usually regarded as a very heterogeneous region in which large and small, rich and poor, more and less advanced countries successfully coexist. Therefore, looking at the EU per se should be sufficient to account for country effects.

Our data have been downloaded in 2014, so that economic, innovation and financial data cover the 2009-2013 period, while ownership data is a snapshot of 2013. Overall, our empirical analysis focuses on 12465 firms.

From a geographical point of view, most of the sample is from the United Kingdom (28\%), followed by France (10\%), Germany (9\%), Romania (9\%), Poland (6\%) and Sweden (6\%); Italy, Bulgaria and Greece account for 3\% each; Spain, Slovakia, Netherlands, Denmark and Belgium for 2\%; negligible percentages are those of the remaining member states.

Despite being all listed on the stock exchange, European firms are quite heterogeneous in terms of size. Even though very large companies account for a good $72 \%$, large (16\%), medium (8\%) and small (4\%) enterprises are still present with notable weights.

Lastly, heterogeneity is preserved also from an industrial perspective. Indeed, our sample covers a wide range of industries, ranging from manufacturing (35\%) to service (27\%), from transport (9\%) to finance $(9 \%)$, from wholesale $(6 \%)$ to retail trade $(4 \%)$ etc. with a very small percentage accruing also to agriculture, forestry and fishing $(2 \%)$.

\section{Descriptive Statistics}

Before turning to the econometric analysis, in this section we provide some descriptive statistics.

As mentioned in Section 1, our main goal is to study the relationship between internationalization and performance in Europe, considering a particular case of firms' global involvement, namely FDI. To analyse all potential correlations between foreign direct investment and performance, we introduce quite a rich taxonomy of FDI operations that groups European enterprises into four mutually exclusive classes, designated only IFDI, only OFDI, both and none.

The label only IFDI applies to firms that only receive inward FDI. Unfortunately, Orbis provides no information regarding either the flows or the stocks of incoming foreign capital. Therefore, we infer foreign participation from ownership data looking at the shareholders' nationality and say that firms receive IFDI when they have at least one foreign shareholder. A similar reasoning applies to the case of only OFDI firms, namely those that only make outward FDI. Based on the available information, we say that firms make outward FDI when they have at least one foreign subsidiary. To complete our 
mutually exclusive taxonomy, the label both applies to European companies that both receive and make FDI, and the label none to those that do not either receive or make FDI. To sum up, only IFDI firms have at least one foreign shareholder but no foreign subsidiaries; only OFDI firms have at least one foreign subsidiary but no foreign shareholders; both firms have at least one foreign shareholder and at least one foreign subsidiary; and none firms have no foreign shareholders and no foreign subsidiaries.

Loosely speaking, one can think that this taxonomy captures different degrees of involvement in FDI operations. Some firms are not involved at all, i.e. they do not act neither as FDI receivers nor as FDI makers on the world stage (none). Others exhibit a kind of intermediate experience in FDI operations, since they are either only receivers (only IFDI) or only makers (only OFDI). Others again enjoy the deepest possible involvement, being engaged both in the inward and in the outward side (both).

In what follows, first we discuss the relative importance of the above-mentioned classes, to provide a general overview of European firms' experience in foreign direct investment. Then we compare international - i.e. only IFDI, only OFDI and both - versus domestic - i.e. none - players with respect to a wide array of performance variables to see whether FDI matters. Put another way, we try to unveil any systematic performance differential between firms characterized by a certain degree of FDI involvement versus their domestic counterparts.

Table 1 provides some descriptive statistics on the relative importance of only IFDI, only OFDI, both and none firms in Europe in 2013.

Table 1: Relative importance of only IFDI, only OFDI, both and none in Europe

\begin{tabular}{|l|ll|}
\hline & Number & $\%$ \\
\hline none & 3701 & $30 \%$ \\
only IFDI & 1958 & $16 \%$ \\
only OFDI & 1423 & $11 \%$ \\
both & 5383 & $43 \%$ \\
total & 12465 & $100 \%$ \\
\hline
\end{tabular}

Source: Authors' elaborations on Orbis data

Based on our data, FDI involvement is quite notable. Indeed, only $30 \%$ of the sample is active neither in inward nor in outward operations. Out of the remaining 70\%, the majority of European enterprises belongs to the both class (43\%), followed by only IFDI (16\%) and only OFDI (11\%).

Figure 1 further dissects this evidence by European country. We believe this is an interesting exercise to see whether the general facts identified above still hold or country-specific patterns emerge.

From Figure 1, it is clear that the deep involvement in FDI - implied by Table 1 on the aggregate - is quite a widespread phenomenon also at the country level. Indeed, apart from Romania, Slovakia and Latvia, the percentage of none firms is less than $50 \%$ in every member state, suggesting that the large majority of the sample has some FDI experience virtually in every corner of the EU. Furthermore, the 
prevalence of both over only IFDI and only OFDI - implied by Table 1 on the aggregate - still emerges at the country level because the percentage of both is much higher than that of only IFDI and only OFDI in every member state, except for Romania and Bulgaria. Based on this evidence, one might infer that not only FDI firms are more numerous than non-FDI firms are but also that, among FDI firms, those enjoying the deepest commitment as both receivers and makers are more numerous than those engaged only in one side are. Lastly, Figure 1 provides some evidence on the relative importance of only IFDI versus only OFDI to be compared with the aggregate picture from Table 1. Interestingly, some country-specific patterns emerge with respect to this issue. Indeed, the general wisdom according to which only IFDI firms are more numerous than only OFDI firms are fails in a considerable group of countries including France, Sweden, Italy, Greece, Spain, Netherlands, Denmark, Belgium, Finland, Cyprus, Austria, Czech republic, Portugal, Luxembourg and Latvia.

Figure 1: Relative importance of only IFDI, only OFDI, both and none firms in Europe, by country

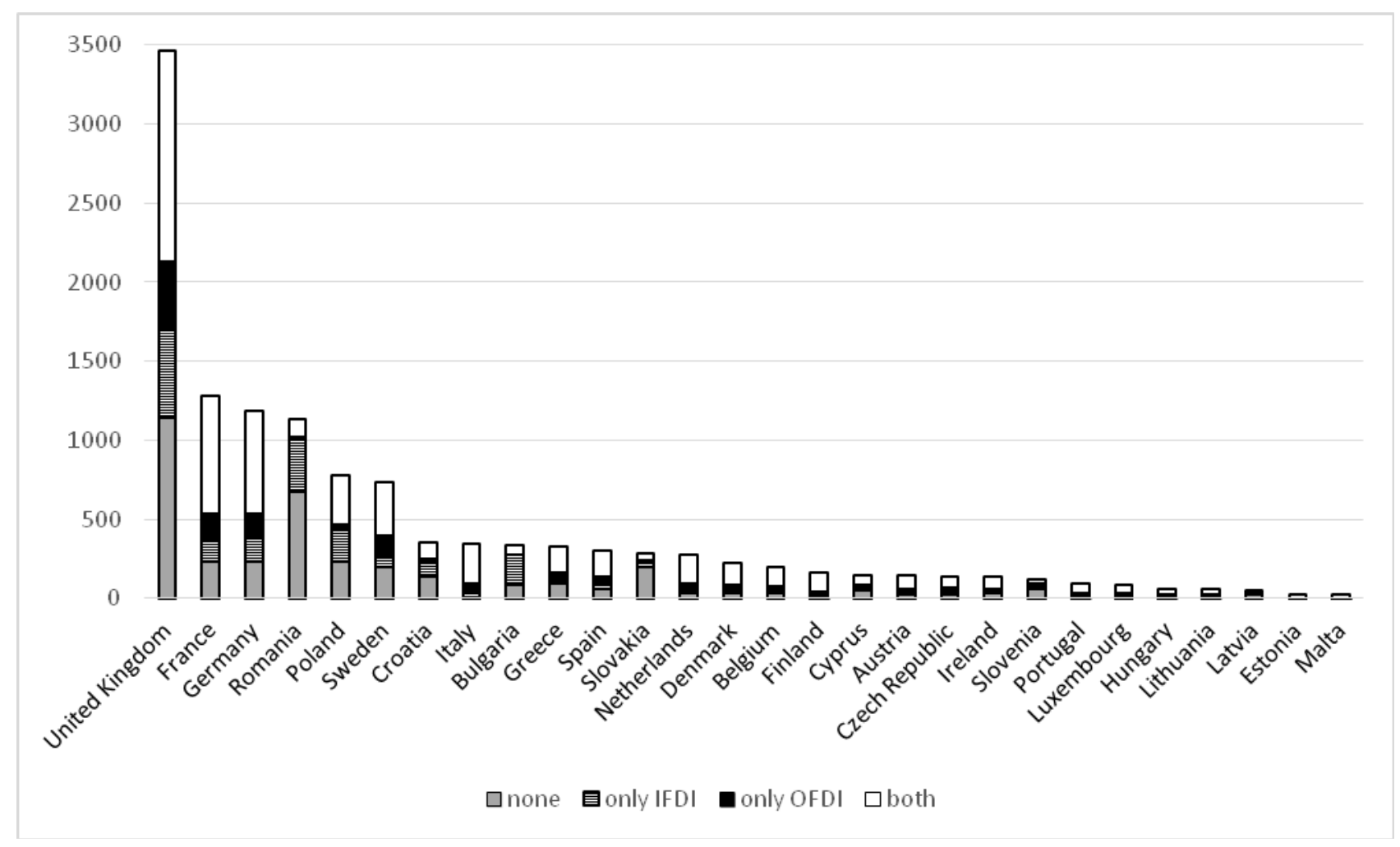

Source: Authors' elaborations on Orbis data

After introducing our taxonomy of FDI operations and discussing its empirical relevance, we now turn to the main question of the paper: is there heterogeneity in performance between firms characterized by different degrees of FDI involvement?

To answer this question, Table 2 provides some descriptive statistics regarding a wide array of performance variables, including Capital, Profitability, Size, Wage, Productivity, Total Factor Productivity (TFP), Intangibles, ROE and ROCE. In selecting these variables, we tried to capture different aspects of firms' performance, related with their economic, innovation and financial strength. 
Capital, Profitability, Size, Wage, Productivity and TFP can be regarded as purely economic indicators, to proxy firms' scale and efficiency; intangible assets (Intangibles) are mostly related to firms' innovative activities, while ROE and ROCE are common measures of financial stability. The reader is referred to Table A1, in the Appendix, for a full variables description.

For every performance measure, Table 2 displays the number of observations, the mean and the standard deviation in each class of FDI firms. Then, to compare international versus domestic firms, mean comparison tests are also run to check whether differences in the mean values between the two groups of firms are statistically significant. To exploit the richness of our FDI taxonomy, Table 2 compares all types of FDI firms - i.e. only IFDI, only OFDI and both - with the base group of none.

Interestingly, all differences reported in Table 2 are positive and statistically significant. This suggests that only IFDI, only OFDI and both tend to systematically differ from none enterprises; moreover, foreign direct investment matters because whatever involvement in FDI is associated with a superior performance compared with the case of purely domestic operations. Notice also that a clear performance ranking of FDI firms emerges and it is robust to the whole set of economic, innovation and financial variables. Indeed, both firms turn out to be better than only OFDI firms; only OFDI firms are better than only IFDI firms; lastly, only IFDI are better than none firms. Put another way, the deepest the firm commitment to foreign direct investment, the highest the performance differential compared with the base category of none enterprises.

Table 2: Performance differentials between only IFDI, only OFDI, both and none firms in Europe

\begin{tabular}{|c|c|c|c|c|c|c|c|c|c|c|c|c|c|c|c|}
\hline \multirow[b]{2}{*}{ Variable } & \multicolumn{3}{|c|}{ none } & \multicolumn{3}{|c|}{ only IFDI } & \multirow{2}{*}{$\begin{array}{c}\begin{array}{c}\text { only } \\
\text { IFDI- } \\
\text { none }\end{array} \\
t-T E S T\end{array}$} & \multicolumn{3}{|c|}{ only OFDI } & \multirow{2}{*}{\begin{tabular}{|c|}
$\begin{array}{c}\text { only } \\
\text { OFDI- } \\
\text { none }\end{array}$ \\
$t-T E S T$ \\
\end{tabular}} & \multicolumn{3}{|c|}{ both } & \multirow{2}{*}{$\begin{array}{c}\begin{array}{c}\text { both- } \\
\text { none }\end{array} \\
t \text {-TEST }\end{array}$} \\
\hline & Obs. & Mean & S.Dev. & Obs. & Mean & S.Dev. & & Obs. & Mean & S.Dev. & & Obs. & Mean & S.Dev. & \\
\hline Capital & 2157 & 8.72 & 2.51 & 1445 & 9.15 & 2.38 & $0.43^{* * *}$ & 883 & 11.60 & 2.26 & $2.88 * * *$ & 4454 & 12.23 & 2.11 & $3.51^{* * *}$ \\
\hline Profitability & 1364 & -4.97 & 30.36 & 1017 & -3.56 & 28.90 & $1.41 * * *$ & 652 & 0.97 & 22.73 & $5.94 * * *$ & 4007 & 1.77 & 18.44 & $6.74 * * *$ \\
\hline Sales & 1473 & 7.48 & 2.23 & 1125 & 8.18 & 2.59 & $0.70 * * *$ & 660 & 10.98 & 2.57 & $3.50 * * *$ & 4048 & 11.94 & 2.25 & $4.46^{* * *}$ \\
\hline Wage & 1505 & 6.35 & 2.01 & 1188 & 6.98 & 2.28 & $0.63 * * *$ & 677 & 9.44 & 2.31 & $3.09 * * *$ & 3803 & 10.32 & 2.15 & $3.97 * * *$ \\
\hline Productivity & 768 & 3.10 & 1.26 & 597 & 3.34 & 1.33 & $0.24 * * *$ & 472 & 4.55 & 1.10 & $1.45^{* * *}$ & 3008 & 4.75 & 1.02 & $1.65^{* * *}$ \\
\hline TFP & 1464 & 5.93 & 1.72 & 1072 & 6.35 & 1.99 & $0.42^{* * *}$ & 652 & 8.38 & 1.70 & $2.45^{* * *}$ & 3826 & 8.89 & 1.51 & $2.96^{* * *}$ \\
\hline Intangibles & 987 & 4.05 & 3.33 & 854 & 5.24 & 3.64 & $1.19 * * *$ & 639 & 8.00 & 3.38 & $3.95 * * *$ & 3975 & 9.28 & 3.27 & $5.23^{* * *}$ \\
\hline ROE & 1782 & -18.64 & 90.66 & 1265 & -16.88 & 91.05 & $1.76^{* * *}$ & 810 & -10.85 & 73.85 & $7.79 *$ & 4254 & -3.44 & 75.10 & $15.20^{* * *}$ \\
\hline ROCE & 1185 & -17.37 & 70.70 & 899 & -10.28 & 77.57 & $7.09^{* * *}$ & 709 & -4.85 & 60.88 & $12.52 *$ & 3922 & 1.26 & 53.12 & $18.63^{* * *}$ \\
\hline
\end{tabular}

* means significant at $10 \%$, ** means significant at $5 \%, * * *$ means significant at $1 \%$.

Source: Authors' computations on Orbis data

\section{Econometric Analysis}

This section further analyses the empirical evidence reported above through econometric regressions.

To study the link between internationalization and performance, taking advantage of our rich taxonomy of FDI operations, we estimate the following model: 
$F D I_{i}=\alpha$ performanc $_{i}+\beta$ firmctrl $_{i}+\gamma$ industryctrl $_{i}+\sigma$ countryctr $_{i}+\varepsilon_{i}$

The dependent variable FDI captures firm i's involvement in foreign direct investment, based on the four mutually exclusive classes introduced in Section 3. In particular, FDI equals 1 in the case of only IFDI, 2 in the case of only OFDI, 3 in the case of both, and 4 in the case of none. Accordingly, Equation (1) is estimated through a multinomial logit model, where the base category is none.

Covariates consist of three main groups: performance is a measure of firm i's performance, according to the economic, innovation and financial variables already exploited in Table 2. They range from Capital to Profitability, from Size to Wage, from Productivity to TFP, from Intangibles to ROE and ROCE. Adding to performance, firmctrl is a matrix containing firm-level variables that may affect the FDI decision but over which we do not have any specific prior; they include a dummy for firm's size (SME), a dummy for public ownership (Public), and a measure of firm's age (Age $)^{4}$. Lastly, industryctrl and countryctrl contain industry and country controls respectively. As far as the industry is concerned, four dummies are included to study the potential effects of belonging to the Manufacturing, Transport, Financial and Service sectors ${ }^{5}$ on the FDI decision; as for the country effects, the dummy Eastern Europe controls for the home market. Estimation results do not qualitatively change if one includes industry fixed effects - through US SIC 2-digits dummies - and country fixed effects - through member-states dummies. However, to keep the table size manageable, we stick to the above mentioned specification which still conceives a neat picture on the internationalization-performance nexus ${ }^{6}$. The Appendix provides a complete variables description (Table A1) and the correlation matrix (Table A2) of econometric regressors.

To avoid simultaneity, FDI refers to the year 2013 - the only year for which ownership data are available $^{7}$ - while independent variables are as of 2009. However, results do not qualitatively change, if one considers another year between 2009 and $2013^{8}$. Although regressors enter Equation (1) with a four-year lag, the cross-sectional nature of our data do not allow any proper causality analysis. For this reason, estimation results should be interpreted as a convenient way of summarizing statistical regularities among variables more than showing the exact direction of causality.

Table 3 summarizes our main findings, and should be read as follows. For every performance measure, three columns are displayed to study the effect of covariates on the choice of a given FDI involvement - out of only IFDI, only OFDI and both - relative to none. Furthermore, two specifications - designated (i) and (ii) - are shown in every column to check robustness of performance to control variables.

\footnotetext{
${ }^{4}$ Unfortunately, Orbis provides no information on the export or import status, therefore we cannot control for them.

${ }^{5}$ Recall from Section 2 that these are the most important sectors in our sample.

${ }^{6}$ More results are available from authors upon request.

${ }^{7}$ See Section 2 on this point.

${ }^{8}$ More results are available from authors upon request.
} 
As the most notable finding, firms enjoying a superior performance tend to choose some FDI involvement relative to no engagement at all. This is because Capital, Profitability, Size, Wage, Productivity, TFP, Intangibles, ROE and ROCE all turn out to be statistically significant with a positive sign, meaning that better enterprises are more likely to experience some foreign direct investment. This result is robust to firm, industry and country controls and it holds irrespective of the performance measure and FDI class. Put another way, only IFDI is more likely to prevail over none the larger the firm's size, capital, productivity, profitability, wages, intangible assets and financial strength; the same is the case for only OFDI and both.

Looking at the magnitude of the performance coefficients, one might push the discussion a bit farther and infer a performance ranking among FDI types. One of the most striking regularities from Table 3 is that the performance coefficient in the only IFDI column is lower than the one in the only OFDI column, which, in turn, is lower than the one in the both column. This result is consistent with previous evidence reported in Table 2 and suggests that, within the group of international players, the best firms are those engaged in inward and outward FDI, followed by those involved only outward, and those involved only inward.

Table 3: Multinomial logit estimation of Equation (1), firm, industry and country controls

\begin{tabular}{|c|c|c|c|c|c|c|}
\hline & \multicolumn{2}{|c|}{ only IFDI } & \multicolumn{2}{|c|}{ only OFDI } & \multicolumn{2}{|c|}{ both } \\
\hline & (i) & (ii) & (i) & (ii) & (i) & (ii) \\
\hline \multirow{14}{*}{$\begin{array}{l}\text { Capital } \\
\text { SME } \\
\text { Age } \\
\text { Public } \\
\text { Eastern Europe } \\
\text { Manufacturing } \\
\text { Transport } \\
\text { Finance } \\
\text { Service } \\
\text { obs } \\
p \text {-value } \\
R^{2} \\
\end{array}$} & $1.082(0.000)^{* * *}$ & $1.114(0.000)^{* * *}$ & $1.873(0.000)^{* * *}$ & $1.756(0.000)^{* * *}$ & $2.136(0.000)^{* * *}$ & $2.104(0.000)^{* * *}$ \\
\hline & & $1.568(0.000)^{* * *}$ & & $1.858(0.003)^{* * *}$ & & $8.571(0.000)^{* * *}$ \\
\hline & & $0.834(0.000)^{* * *}$ & & $0.907(0.040)^{* *}$ & & $0.779(0.000)^{* * *}$ \\
\hline & & $2.932(0.000)^{* * *}$ & & $1.336(0.007)^{* * *}$ & & $3.745(0.000)^{* * *}$ \\
\hline & & $0.644(0.000)^{* * *}$ & & $0.188(0.000)^{* * *}$ & & $0.221(0.000)^{* * *}$ \\
\hline & & $1.395(0.001)^{* * *}$ & & $1.727(0.000)^{* * *}$ & & $1.811(0.000)^{* * *}$ \\
\hline & & $1.143(0.359)$ & & $1.741(0.002)^{* * *}$ & & $1.076(0.612)$ \\
\hline & & $0.854(0.253)$ & & $0.761(0.080)^{*}$ & & $0.275(0.000)^{* * *}$ \\
\hline & & $0.967(0.749)$ & & $1.433(0.012)^{* *}$ & & $1.220(0.059)^{*}$ \\
\hline & 8939 & 8310 & 8939 & 8310 & 8939 & 8310 \\
\hline & $0.000^{* * *}$ & $0.000 * * *$ & $0.000^{* * *}$ & $0.000 * * *$ & $0.000 * * *$ & $0.000 * * *$ \\
\hline & 0.175 & 0.237 & 0.175 & 0.237 & 0.175 & 0.237 \\
\hline & \multicolumn{2}{|c|}{ only IFDI } & \multicolumn{2}{|c|}{ only OFDI } & \multicolumn{2}{|c|}{ both } \\
\hline & (i) & (ii) & (i) & (ii) & (i) & (ii) \\
\hline Profitability & $1.002(0.000)^{* * *}$ & $1.001(0.485)$ & $1.011(0.000)^{* * *}$ & $1.010(0.000)^{* * *}$ & $1.012(0.000)^{* * *}$ & $1.012(0.000)^{* * *}$ \\
\hline SME & & $1.632(0.000)^{* * *}$ & & $6.900(0.000)^{* * *}$ & & $36.073(0.000) * * *$ \\
\hline Age & & $1.069(0.166)$ & & $1.379(0.000)^{* * *}$ & & $1.336(0.000)^{* * *}$ \\
\hline Public & & $2.342(0.000)^{* * *}$ & & $0.810(0.130)$ & & $1.933(0.000)^{* * *}$ \\
\hline Eastern Europe & & $0.570(0.000)^{* * *}$ & & $0.089(0.000)^{* * *}$ & & $0.081(0.000)^{* * *}$ \\
\hline Manufacturing & & $1.262(0.047)^{* *}$ & & $1.990(0.000)^{* * *}$ & & $1.828(0.000)^{* * *}$ \\
\hline Transport & & $1.116(0.520)$ & & $2.469(0.000)^{* * *}$ & & $1.740(0.000)^{* * *}$ \\
\hline Finance & & $1.126(0.627)$ & & $1.697(0.039)^{* *}$ & & $0.974(0.000)^{* * *}$ \\
\hline Service & & $0.807(0.097)^{*}$ & & $1.565(0.007)^{* * *}$ & & $1.155(0.205)$ \\
\hline obs & 7040 & 6517 & 7040 & 6517 & 7040 & 6517 \\
\hline p-value & $0.000 * * *$ & $0.000 * * *$ & $0.000 * * *$ & $0.000 * * *$ & $0.000 * * *$ & $0.000 * * *$ \\
\hline \multirow[t]{3}{*}{$R^{2}$} & 0.007 & 0.158 & 0.007 & 0.158 & 0.007 & 0.158 \\
\hline & \multicolumn{2}{|c|}{ only IFDI } & \multicolumn{2}{|c|}{ only OFDI } & \multicolumn{2}{|c|}{ both } \\
\hline & (i) & (ii) & (i) & (ii) & (i) & (ii) \\
\hline Sales & $1.125(0.000)^{* * *}$ & $1.132(0.000)^{* * *}$ & $1.967(0.000)^{* * *}$ & $1.864(0.000)^{* * *}$ & $2.383(0.000)^{* * *}$ & $2.257(0.000)^{* * *}$ \\
\hline SME & & $1.579(0.000)^{* * *}$ & & $1.872(0.013)^{* *}$ & & $10.229(0.000)^{* * *}$ \\
\hline Age & & $0.928(0.121)$ & & $0.949(0.399)$ & & $0.816(0.000)^{* * *}$ \\
\hline Public & & $2.394(0.000)^{* * *}$ & & $0.612(0.002)^{* * *}$ & & $1.287(0.069)^{*}$ \\
\hline Eastern Europe & & $0.554(0.000)^{* * *}$ & & $0.149(0.000)^{* * *}$ & & $0.177(0.000)^{* * *}$ \\
\hline Manufacturing & & $1.252(0.047)^{* *}$ & & $1.454(0.019)^{* *}$ & & $1.332(0.016)^{* *}$ \\
\hline Transport & & $1.076(0.656)$ & & $1.567(0.037)^{* *}$ & & $0.962(0.819)$ \\
\hline
\end{tabular}




\begin{tabular}{|c|c|c|c|c|c|c|}
\hline \multirow[t]{3}{*}{$\begin{array}{l}\text { Finance } \\
\text { Service } \\
\text { obs } \\
p \text {-value } \\
R^{2} \\
\end{array}$} & $\begin{array}{l}7306 \\
0.000 * * * \\
0.231 \\
\end{array}$ & $\begin{array}{l}1.452(0.138) \\
0.816(0.104) \\
6731 \\
0.000 * * * \\
0.286\end{array}$ & $\begin{array}{l}7306 \\
0.000 * * * \\
0.231 \\
\end{array}$ & $\begin{array}{l}5.390(0.000)^{* * *} \\
1.364(0.076)^{*} \\
6731 \\
0.000^{* * *} \\
0.286\end{array}$ & $\begin{array}{l}7306 \\
0.000 * * * \\
0.231 \\
\end{array}$ & $\begin{array}{l}2.519(0.000)^{* * *} \\
0.986(0.918) \\
6731 \\
0.000^{* * *} \\
0.286\end{array}$ \\
\hline & \multicolumn{2}{|c|}{ only IFDI } & \multicolumn{2}{|c|}{ only OFDI } & \multicolumn{2}{|c|}{ both } \\
\hline & (i) & (ii) & (i) & (ii) & (i) & (ii) \\
\hline $\begin{array}{l}\text { Wage } \\
\text { SME } \\
\text { Age } \\
\text { Public } \\
\text { Eastern Europe } \\
\text { Manufacturing } \\
\text { Transport } \\
\text { Finance } \\
\text { Service } \\
\text { obs } \\
p \text {-value } \\
R^{2} \\
\end{array}$ & $\begin{array}{l}7173 \\
0.000^{* * *} \\
0.218 \\
\end{array}$ & $\begin{array}{l}1.138(0.000)^{* * *} \\
1.624(0.000)^{* * *} \\
0.915(0.054)^{*} \\
2.592(0.000)^{* * *} \\
0.519(0.000)^{* * *} \\
1.255(0.039)^{* *} \\
1.053(0.752) \\
1.198(0.378) \\
0.972(0.812) \\
6659 \\
0.000 * * * \\
0.270\end{array}$ & $\begin{array}{l} \\
\\
\\
\\
\\
\\
\\
7173 \\
0.000^{* * *} \\
0.218 \\
\end{array}$ & $\begin{array}{l}1.881(0.000)^{* * *} \\
2.773(0.000)^{* * *} \\
0.999(0.987) \\
0.844(0.215) \\
0.173(0.000)^{* * *} \\
1.636(0.001)^{* * *} \\
2.013(0.001)^{* * *} \\
3.641(0.000)^{* * *} \\
1.838(0.000)^{* * *} \\
6659 \\
0.000 * * * \\
0.270\end{array}$ & $\begin{array}{l}7173 \\
0.000 * * * \\
0.218 \\
\end{array}$ & $\begin{array}{l}2.271(0.000)^{* * *} \\
9.264(0.000)^{* * *} \\
0.862(0.002)^{* * *} \\
2.045(0.000)^{* * *} \\
0.179(0.000)^{* * *} \\
1.734(0.000)^{* * *} \\
1.538(0.011)^{* *} \\
2.169(0.000)^{* * *} \\
1.940(0.000)^{* * *} \\
6659 \\
0.000 * * * \\
0.270\end{array}$ \\
\hline \multirow{2}{*}{$R^{2}$} & \multicolumn{2}{|c|}{ only IFDI } & \multicolumn{2}{|c|}{ only OFDI } & \multicolumn{2}{|c|}{ both } \\
\hline & (i) & (ii) & (i) & (ii) & (i) & (ii) \\
\hline $\begin{array}{l}\text { Productivity } \\
\text { SME } \\
\text { Age } \\
\text { Public } \\
\text { Eastern Europe } \\
\text { Manufacturing } \\
\text { Transport } \\
\text { Finance } \\
\text { Service } \\
\text { obs } \\
p \text {-value } \\
R^{2} \\
\end{array}$ & $\begin{array}{l}1.153(0.000)^{* * *} \\
\\
\\
4845 \\
0.000 * * * \\
0.145 \\
\end{array}$ & $\begin{array}{l}1.082(0.130) \\
1.810(0.001)^{* * *} \\
1.080(0.275) \\
2.581(0.000)^{* * *} \\
0.473(0.000)^{* * *} \\
1.113(0.510) \\
0.801(0.340) \\
1.018(0.959) \\
0.711(0.057)^{*} \\
4479 \\
0.000^{* * *} \\
0.215\end{array}$ & $\begin{array}{l} \\
\\
\\
\\
\\
\\
\\
4845 \\
0.000 * * * \\
0.145 \\
\end{array}$ & $\begin{array}{l}1.934(0.000)^{* * *} \\
4.520(0.000)^{* * *} \\
1.285(0.001)^{* * *} \\
1.235(0.243) \\
0.160(0.000)^{* * *} \\
1.900(0.001)^{* * *} \\
1.465(0.143) \\
1.689(0.135) \\
1.311(0.211) \\
4479 \\
0.000 * * * \\
0.215\end{array}$ & $\begin{array}{l}4845 \\
0.000^{* * *} \\
0.145 \\
\end{array}$ & $\begin{array}{l}2.274(0.000)^{* * *} \\
19.478(0.000)^{* * *} \\
1.210(0.002)^{* * *} \\
2.787(0.000)^{* * *} \\
0.111(0.000)^{* * *} \\
2.017(0.000)^{* * *} \\
1.161(0.472) \\
0.989(0.755) \\
1.253(0.170) \\
4479 \\
0.000 * * * \\
0.215\end{array}$ \\
\hline \multirow{2}{*}{$R^{2}$} & \multicolumn{2}{|c|}{ only IFDI } & \multicolumn{2}{|c|}{ only OFDI } & \multicolumn{2}{|c|}{ both } \\
\hline & (i) & (ii) & (i) & (ii) & (i) & (ii) \\
\hline $\begin{array}{l}\text { TFP } \\
\text { SME } \\
\text { Age } \\
\text { Public } \\
\text { Eastern Europe } \\
\text { Manufacturing } \\
\text { Transport } \\
\text { Finance } \\
\text { Service } \\
\text { obs } \\
p \text {-value } \\
R^{2} \\
\end{array}$ & $\begin{array}{l} \\
\\
7014 \\
0.000^{* * *} \\
0.209 \\
\end{array}$ & $\begin{array}{l}1.115(0.000)^{* * *} \\
1.523(0.001)^{* * *} \\
0.982(0.710) \\
2.767(0.000)^{* * *} \\
0.542(0.000)^{* * *} \\
1.251(0.045)^{* *} \\
1.037(0.829) \\
1.270(0.313) \\
0.776(0.045)^{* *} \\
6514 \\
0.000 * * * \\
0.260 \\
\end{array}$ & $\begin{array}{l} \\
\\
\\
\\
\\
\\
7014 \\
0.000^{* * *} \\
0.209 \\
\end{array}$ & $\begin{array}{l}1.938(0.000)^{* * *} \\
2.591(0.000)^{* * *} \\
1.041(0.505) \\
0.955(0.746) \\
0.152(0.000)^{* * *} \\
1.705(0.001)^{* * *} \\
1.954(0.002)^{* * *} \\
2.491(0.000)^{* * *} \\
1.308(0.122) \\
6514 \\
0.000 * * * \\
0.260 \\
\end{array}$ & $\begin{array}{l}7014 \\
0.000^{* * *} \\
0.209\end{array}$ & $\begin{array}{l}2.474(0.000)^{* * *} \\
10.645(0.000)^{* * *} \\
0.940(0.188) \\
2.113(0.000)^{* * *} \\
0.168(0.000)^{* * *} \\
1.506(0.000)^{* * *} \\
1.144(0.435) \\
1.273(0.282) \\
1.010(0.936) \\
6514 \\
0.000 * * * \\
0.260\end{array}$ \\
\hline \multirow{2}{*}{$R^{2}$} & \multicolumn{2}{|c|}{ only IFDI } & \multicolumn{2}{|c|}{ only OFDI } & \multicolumn{2}{|c|}{ both } \\
\hline & (i) & (ii) & (i) & (ii) & (i) & (ii) \\
\hline $\begin{array}{l}\text { Intangibles } \\
\text { SME } \\
\text { Age } \\
\text { Public } \\
\text { Eastern Europe } \\
\text { Manufacturing } \\
\text { Transport } \\
\text { Finance } \\
\text { Service } \\
\text { obs } \\
p \text {-value } \\
R^{2} \\
\end{array}$ & $\begin{array}{l}6455 \\
0.000^{* * *} \\
0.147 \\
\end{array}$ & $\begin{array}{l}1.106(0.000)^{* * *} \\
2.029(0.000)^{* * *} \\
1.026(0.621) \\
2.580(0.000)^{* * *} \\
0.701(0.004)^{* * *} \\
1.294(0.045)^{* *} \\
1.148(0.493) \\
0.849(0.545) \\
0.896(0.462) \\
5975 \\
0.000 * * * \\
0.202 \\
\end{array}$ & $\begin{array}{l}6455 \\
0.000^{* * *} \\
0.147 \\
\end{array}$ & $\begin{array}{l}1.312(0.000)^{* * *} \\
4.806(0.000)^{* * *} \\
1.536(0.000)^{* * *} \\
0.826(0.203) \\
0.291(0.000)^{* * *} \\
1.780(0.000)^{* * *} \\
2.186(0.001)^{* * *} \\
2.391(0.001)^{* * *} \\
1.957(0.000)^{* * *} \\
5975 \\
0.000 * * * \\
0.202 \\
\end{array}$ & $\begin{array}{l}6455 \\
0.000 * * * \\
0.147 \\
\end{array}$ & $\begin{array}{l}1.501(0.000)^{* * *} \\
20.087(0.000)^{* * *} \\
1.456(0.000)^{* * *} \\
1.772(0.000)^{* * *} \\
0.450(0.000)^{* * *} \\
1.843(0.000)^{* * *} \\
1.712(0.004)^{* * *} \\
1.221(0.381) \\
1.688(0.000)^{* * *} \\
5975 \\
0.000 * * * \\
0.202\end{array}$ \\
\hline \multirow{2}{*}{$R^{2}$} & \multicolumn{2}{|c|}{ only IFDI } & \multicolumn{2}{|c|}{ only OFDI } & \multicolumn{2}{|c|}{ both } \\
\hline & (i) & (ii) & (i) & (ii) & (i) & (ii) \\
\hline $\begin{array}{l}\text { ROE } \\
\text { SME } \\
\text { Age } \\
\text { Public } \\
\text { Eastern Europe } \\
\text { Manufacturing } \\
\text { Transport }\end{array}$ & $1.000(0.000)^{* * *}$ & $\begin{array}{l}0.100(0.653) \\
1.888(0.000)^{* * *} \\
0.939(0.121) \\
2.731(0.000)^{* * *} \\
0.569(0.000)^{* * *} \\
1.421(0.001)^{* * *} \\
1.162(0.344)\end{array}$ & $1.001(0.000)^{* * *}$ & $\begin{array}{l}1.001(0.167) \\
4.834(0.000)^{* * *} \\
1.283(0.000)^{* * *} \\
1.197(0.107) \\
0.110(0.000)^{* * *} \\
1.824(0.000)^{* * *} \\
2.351(0.000)^{* * *}\end{array}$ & $1.002(0.000)^{* * *}$ & $\begin{array}{l}1.002(0.000)^{* * *} \\
29.086(0.000)^{* * *} \\
1.244(0.000)^{* * *} \\
3.435(0.000)^{* * *} \\
0.094(0.000)^{* * *} \\
2.008(0.000)^{* * *} \\
1.830(0.000)^{* * *}\end{array}$ \\
\hline
\end{tabular}




\begin{tabular}{|c|c|c|c|c|c|c|}
\hline \multirow[t]{3}{*}{$\begin{array}{l}\text { Finance } \\
\text { Service } \\
\text { obs } \\
p \text {-value } \\
R^{2} \\
\end{array}$} & $\begin{array}{l}8111 \\
0.000^{* * *} \\
0.003\end{array}$ & $\begin{array}{l}0.951(0.744) \\
0.990(0.933) \\
7541 \\
0.000 * * * \\
0.137\end{array}$ & $\begin{array}{l}8111 \\
0.000^{* * *} \\
0.003\end{array}$ & $\begin{array}{l}1.267(0.138) \\
1.438(0.013)^{* *} \\
7541 \\
0.000 * * * \\
0.137\end{array}$ & $\begin{array}{l}8111 \\
0.000^{* * *} \\
0.003\end{array}$ & $\begin{array}{l}0.547(0.000)^{* * *} \\
1.337(0.004)^{* * *} \\
7541 \\
0.000 * * * \\
0.137\end{array}$ \\
\hline & \multicolumn{2}{|c|}{ only IFDI } & \multicolumn{2}{|c|}{ only OFDI } & \multicolumn{2}{|c|}{ both } \\
\hline & (i) & (ii) & (i) & (ii) & (i) & (ii) \\
\hline ROCE & $0.999(0.000)^{* * *}$ & $0.999(0.036)^{* *}$ & $1.001(0.000)^{* * *}$ & $1.001(0.156)$ & $1.004(0.000)^{* * *}$ & $1.003(0.000)^{* * *}$ \\
\hline SME & & $2.000(0.000)^{* * *}$ & & $5.615(0.000)^{* * *}$ & & $43.187(0.000)^{* * *}$ \\
\hline Age & & $0.976(0.631)$ & & $1.279(0.000)^{* * *}$ & & $1.241(0.000)^{* * *}$ \\
\hline Public & & $2.557(0.000)^{* * *}$ & & $1.060(0.639)$ & & $2.982(0.000)^{* * *}$ \\
\hline Eastern Europe & & $0.561(0.000)^{* * *}$ & & $0.102(0.000)^{* * *}$ & & $0.083(0.000)^{* * *}$ \\
\hline Manufacturing & & $1.162(0.250)$ & & $1.574(0.003)^{* * *}$ & & $1.654(0.000)^{* * *}$ \\
\hline Transport & & $0.963(0.840)$ & & $1.954(0.001)^{* * *}$ & & $1.494(0.010)^{* * *}$ \\
\hline Finance & & $0.914(0.643)$ & & $1.183(0.382)$ & & $0.506(0.000)^{* * *}$ \\
\hline Service & & $0.759(0.055)^{*}$ & & $1.278(0.140)$ & & $1.080(0.523)$ \\
\hline obs & 6715 & 6216 & 6715 & 6216 & 6715 & 6216 \\
\hline p-value & $0.000 * * *$ & $0.000 * * *$ & $0.000 * * *$ & $0.000 * * *$ & $0.000 * * *$ & $0.000 * * *$ \\
\hline$R^{2}$ & 0.006 & 0.139 & 0.006 & 0.139 & 0.006 & 0.139 \\
\hline
\end{tabular}

Source: Authors' computations on Orbis data

To conclude, FDI really matters to explain the link between internationalization and performance in Europe. This is because: first, better enterprises internationalize, choosing to experience some FDI only IFDI, only OFDI or both - rather than none; second, within the group of international players, better performance tends to be associated with deeper FDI involvement.

As far as control variables are concerned, it is worth mentioning that small and medium, publicly owned and manufacturing enterprises are more likely to undertake some FDI, while location in Eastern Europe tends to be negatively and significantly correlated with foreign direct investment. On the contrary, from Table 3, evidence on age, financial, transport and service sectors is less clear cut and conclusive.

\section{Conclusion}

This paper investigates the link between internationalization and performance in Europe. It takes a microeconomic perspective and studies how FDI experience relates with European firms' economic, innovation and financial performance.

Given the well-established portrait of European traders emerging from previous studies ${ }^{9}$, we contribute to the ongoing debates along three dimensions. First, we identify internationalization with FDI, rather than import and/or export. In doing this, we provide quite an original taxonomy of foreign direct investment combining inward and outward operations in four mutually exclusive classes of FDI experience. Second, we employ a wide array of performance variables adding to productivity, to see which aspects of firms' life are mostly related with the FDI decision. Third, we draw on a large longitudinal dataset, relying on Orbis (2014), that covers Europe as a whole. To the best of our

\footnotetext{
${ }^{9}$ See Section 1 on this issue.
} 
knowledge, this is the first paper using Orbis data to account for all potential links between FDI and performance of European enterprises.

Our descriptive statistics - reported in Section 3 - document that FDI experience in Europe is quite notable, involving roughly $70 \%$ of the sample. Mean comparisons tests between FDI and domestic firms further suggest that there are significant performance differences between the two groups, with FDI players outperforming domestic ones with respect to all economic, innovation and financial indicators.

Consistent evidence emerges from Section 4, which is devoted to the econometric analysis. Multinomial logit estimates reveal that firms experiencing some FDI (either inward, outward or both) enjoy a superior performance compared with purely domestic enterprises. Moreover, within the class of FDI players, firms engaged in inward and outward FDI turn out to be better than those engaged only in outward FDI, which are better than those engaged only in inward FDI. These results are robust to several performance measures and alternative specifications including firm, industry and country controls.

To conclude, when discussing about internationalization and performance in Europe, FDI is really an issue. It is not only a matter of being or not being involved, but also a matter of how - inward or outward - and how much -inward, outward or both - firms are actually involved. Indeed, our descriptive statistics and econometric analysis point to the existence of a strong and robust performance ranking a) between FDI and non-FDI firms and b) among firms experiencing only inward FDI, only outward FDI or both.

Hopefully, these results contribute to the ongoing debate on the internationalization-performance nexus, enriching our understanding of the role of foreign direct investment in Europe.

While this represents, in our view, an important step, we are aware of some data limitations that plague our current analysis and limits its scope. On the one hand, the unavailability of information on incoming and outgoing capital, as well as ownership percentages, force us to use proxies for inward and outward FDI that might not capture the exact FDI experience of the sampled enterprises. On the other hand, the longitudinal nature of our data prevents from performing proper causality tests so that we cannot say whether FDI involvement causes performance or the other way around. Put another way, although promising in asserting the importance of FDI, our results do not help discriminate between self-selection and learning-by-internationalization. This second issue is particularly important when one aims at deriving some policy implications. Broadly speaking, there is wide consensus on the fact that promoting internationalisation and fostering economic performance are two desirable outcomes of the policymaking process. Nonetheless, answering the so called chicken-and-egg 
question is unescapable to translate these theoretical goals into practical actions. This is something that future analysis could improve on. 


\section{References}

Altomonte, C., \& Bekes, G. (2010). Trade complexity and productivity. Centre for Firms in the Global Economy (CeFiG) Working Paper 1.

Andersson, M., Loof, H., \& Johansson, S. (2008). Productivity and international trade: Firm level evidence from a small open economy. Review of World Economics, 144(4), 774-801.

Bekes, G., Harasztosi, P., \& Murakozy, B. (2011). Firms and products in international trade: Evidence from Hungary. Economic Systems, 35(1), 4-24.

Breinlich, H., \& Criscuolo, C. (2011). International Trade in Services: A Portrait of Importers and Exporters. Journal of International Economics, 84(2), 188-206.

Castellani, D., Serti, F., \& Tomasi, C. (2010). Firms in International Trade: Importers and Exporters Heterogeneity in the Italian Manufacturing Industry. The World Economy, 33(3), 424-457.

Castellani, D. (2006). L'impatto della presenza delle imprese multinazionali sul contesto locale. In S. Mariotti S. \& L. Piscitello (Eds.), Multinazionali, innovazione e strategie per la competitività. Bologna: il Mulino.

Damijan, J.P, \& Kostevc, C. (2006). Learning-by-exporting: Continuous productivity improvements or capacity utilization effects? Evidence from Slovenian firms. Review of World Economics, 142 (3), 599-614.

De Loecker, J. (2007). Do exports generate higher productivity? Evidence from Slovenia. Journal of International Economics, 73(1), 69-98.

Eaton, J., Kortum, S., \& Kramarz, F. (2004). Dissecting Trade: Firms, Industries and Export Destination. American Economic Review, 94(2), 150-154.

Eliasson, K., Hansson, P., \& Lindvert, M. (2009). Do firms learn by exporting or learn to export? Evidence from small and medium-sized enterprises (SMEs) in Swedish manufacturing. Orebro University, Swedish Business School Working Paper 15.

Eriksson, T., Smeets, V., \& Warzynski, F. (2009). Small open economy firms in international trade: Evidence from Danish transaction-level data, Danish Economic Journal, 147(2), 175-194.

Esteve-Perez, S., Pallardo-Lopez, V., \& Requena-Silvente, F. (2013). The duration of firm-destination export relationships: Evidence from Spain, 1997-2006. Economic Inquiry, 51(1), 159-180.

Gorg, H., \& Spaliara, M.E. (2014). Financial health, exports, and firm survival: A comparison of British and French firms. Economica, 81(323), 419-444.

Greenaway, D., \& Kneller, R. (2007). Firm Heterogeneity, Exporting and Foreign Direct Investment: a Survey. The Economic Journal, 117(517), F134-F161. 
Haller, S. A., Damijan, J., Kaitila, V., Kostevc, Č., Maliranta, M., Milet, E., \& Rojec, M. (2014). Trading firms in the services sectors - Comparable evidence from four EU countries. Review of World Economics, forthcoming.

Hayakawa, K., Kimura, F., \& Machikita, T. (2012). Globalization and Productivity: a Survey of FirmLevel Analysis. Journal of Economic Surveys, 26(2), 332-350.

ISGEP (2008). Understanding Cross-Country Differences in Exporter Premiums: Comparable Evidence from 14 Countries. Review of World Economics, 144(4), 596-635.

Kox, H.L., \& Rojas-Romagosa, H. (2010). Exports and productivity selection effects for Dutch firms. De Economist, 158(3), 295-322.

Lawless, M. (2009). Firm export dynamics and the geography of trade. Journal of International Economics, 77(2), 245-254.

Lopez, R.A. (2005) Trade and Growth: Reconciling the Macroeconomic and Microeconomic Evidence. Journal of Economic Surveys 19(4), 623-648.

Mayer, T., \& Ottaviano, G.I.P. (2008). I pochi eletti: nuovi fatti sull'internazionalizzazione delle imprese europee. L'industria, 29(2), 221-244.

Melitz, M.J. (2003). The impact of Trade on Intra-Industry Reallocations and Aggregate Industry Productivity. Econometrica, 71(6), 1661-1694.

Muuls, M., \& Pisu, M. (2009). Imports and exports at the level of the firm: Evidence from Belgium. The World Economy, 32(5), 692-734.

Pisu, M. (2008). Export destination and learning-by-exporting: Evidence from Belgium, National Bank of Belgium, Working Paper 140.

Ruane, F., \& Sutherland, J. (2005). Export performance and destination characteristics of Irish manufacturing industry. Review of World Economics, 141(3), 442-459.

Serti, F., Tomasi, C., \& Zanfei, A. (2010). Who Trades with Whom? Exploring the Links between Firm's International Activities, Skills and Wages. Review of International Economics, 18(5), 951-971. Silva, A., Afonso, O., \& Africano, A.P. (2010a). Do Portugese manufacturing firms self select to exports?. Universidade de Porto, Facultade de Economia de Porto, Working Paper 371.

Silva, A., Afonso, O., \& Africano, A.P.( 2013). Economic performance and international trade engagement: The case of Portugese manufacturing firms. International Economics and Economic Policy, 10(4), 521-547.

Singh, T. (2010). Does International Trade Cause Economic Growth? A Survey. The World Economy, $33(11), 1517-1564$ 
Temouri, Y., Vogel, A., \& Wagner, J. (2013). Self selection into export markets by business services firms- Evidence from France, Germany and the United Kingdom. Structural Change and Economic Dynamics, 25(2), 146-158.

Vogel, A., \& Wagner, J. (2010). Higher productivity in German manufacturing firms: Self-selection, learning from importing, or both?. Review of World Economics, 145(4), 641-665.

Vogel, A. (2011). Exporter performance in German business services sector. The Service Industries Journal, 31(7), 1015-1031.

Wagner, J. (2007). Exports and Productivity: A Survey of the Evidence from Firm-Level Data. The World Economy, 30(1), 60-72.

Wagner, J. (2012). International Trade and Firm Performance: A Survey of Empirical Studies since 2006. Review of World Economics, 148(2), 235-267.

Wilhelmsson, F., \& Kozlov, K. (2007). Exports and productivity of Russian firms: In search of causality. Economic Change and Restructuring, 40(4), 361-385. 


\section{Appendix}

This Section provides a complete variables description (Table A1) and the correlation matrix of econometric regressors (Table A2).

Table A1: Variables description

\begin{tabular}{|c|c|}
\hline Variable & Description \\
\hline only IFDI & $\begin{array}{l}\text { Dummy variable; } 1 \text { if the firm has at least one foreign shareholder and } 0 \text { foreign subsidiaries, } 0 \\
\text { otherwise. }\end{array}$ \\
\hline only OFDI & $\begin{array}{l}\text { Dummy variable; } 1 \text { if the firm has at least one foreign subsidiary and } 0 \text { foreign shareholders, } 0 \\
\text { otherwise. }\end{array}$ \\
\hline both & $\begin{array}{l}\text { Dummy variable; } 1 \text { if the firm has at least one foreign shareholder and } 1 \text { foreign subsidiary, } 0 \\
\text { otherwise. }\end{array}$ \\
\hline none & Dummy variable; 1 if the firm has no foreign shareholders and no foreign subsidiaries, 0 otherwise. \\
\hline FDI & Discrete variable; 1 if only IFDI, 2 if only OFDI, 3 if both, 4 if none. \\
\hline Capital & Natural logarithm of firm's total assets. \\
\hline Profitability & Profit margin, defined as net profit over revenues. \\
\hline Sales & Natural logarithm of firm's sales. \\
\hline Wage & Natural logarithm of the total cost of labour incurred by the firm. \\
\hline Productivity & Natural logarithm of labour productivity, defined as value added over employees. \\
\hline TFP & $\begin{array}{l}\text { Natural logarithm of firm's total factor productivity. Total factor productivity is estimated according } \\
\text { to the Levinsohn and Petrin (2003) method, to deal with simultaneity and selection bias. In particular, } \\
\text { we assume the production function of firm } i \text {, at a given point in time, to be Cobb-Douglas, and the } \\
\text { logarithm of firm's output (measured by total revenues) to be a function of the logarithm of the freely } \\
\text { variable inputs labour (measured by the number of employees) and intermediate input (measured by } \\
\text { material costs) and the logarithm of the state variable capital (measured by total assets). All variables } \\
\text { in the Levinsohn-Petrin estimation of TFP are deflated by the Producer Price Index for the } \\
\text { appropriate two-digit Us SIC industry. }\end{array}$ \\
\hline Intangibles & Natural logarithm of firm's intangible assets. \\
\hline ROE & Firm's Return on Equity, defined as net income over total equity. \\
\hline ROCE & $\begin{array}{l}\text { Firm's Return on Capital Employed, defined as Earnings Before Interest and Tax (EBIT) over capital } \\
\text { employed. }\end{array}$ \\
\hline SME & Dummy variable; 1 if the firm is a small or medium enterprise, 0 otherwise. \\
\hline Age & $\begin{array}{l}\text { Natural logarithm of firm's age, defined as the difference between } 2009 \text { and the year of firm's } \\
\text { establishment. }\end{array}$ \\
\hline Public & Dummy variable; 1 if the firm is publicly owned. \\
\hline Eastern Europe & $\begin{array}{l}\text { Dummy variable; } 1 \text { if the firm is located in Eastern Europe (Lithuania, Estonia, Latvia, Hungary, } \\
\text { Romania, Poland, Croatia, Bulgaria, Slovakia, Czech Republic, Slovenia). }\end{array}$ \\
\hline Manufacturing & $\begin{array}{l}\text { Dummy variable; } 1 \text { if the firm belongs to the manufacturing industry (US SIC } 2 \text { digit classification, } \\
\text { divisions 20-39). }\end{array}$ \\
\hline Transport & $\begin{array}{l}\text { Dummy variable; } 1 \text { if the firm belongs to the transport industry (US SIC } 2 \text { digit classification, } \\
\text { divisions 40-49). }\end{array}$ \\
\hline Finance & $\begin{array}{l}\text { Dummy variable; } 1 \text { if the firm belongs to the finance industry (US SIC } 2 \text { digit classification, } \\
\text { divisions 60-67). }\end{array}$ \\
\hline Service & $\begin{array}{l}\text { Dummy variable; } 1 \text { if the firm belongs to the service industry (US SIC } 2 \text { digit classification, divisions } \\
70-89 \text { ). }\end{array}$ \\
\hline
\end{tabular}


Table A2: Correlation matrix of econometric regressors

\begin{tabular}{|c|c|c|c|c|c|c|c|c|c|c|c|c|c|c|c|c|c|}
\hline & 1 & 2 & 3 & 4 & 5 & 6 & 7 & 8 & 9 & 10 & 11 & 12 & 13 & 14 & 15 & 16 & 17 \\
\hline Capital (1) & 1.00 & & & & & & & & & & & & & & & & \\
\hline Profitability (2) & 0.18 & 1.00 & & & & & & & & & & & & & & & \\
\hline Sales (3) & 0.90 & 0.19 & 1.00 & & & & & & & & & & & & & & \\
\hline Wage (4) & 0.87 & 0.17 & 0.94 & 1.00 & & & & & & & & & & & & & \\
\hline Productivity (5) & 0.69 & 0.45 & 0.72 & 0.69 & 1.00 & & & & & & & & & & & & \\
\hline TFP (6) & 0.84 & 0.21 & 0.96 & 0.86 & 0.76 & 1.00 & & & & & & & & & & & \\
\hline Intangibles (7) & 0.74 & 0.14 & 0.74 & 0.78 & 0.65 & 0.72 & 1.00 & & & & & & & & & & \\
\hline ROE (8) & 0.16 & 0.44 & 0.19 & 0.13 & 0.23 & 0.19 & 0.10 & 1.00 & & & & & & & & & \\
\hline ROCE (9) & 0.20 & 0.44 & 0.22 & 0.15 & 0.21 & 0.23 & 0.11 & 0.76 & 1.00 & & & & & & & & \\
\hline SME (10) & 0.33 & 0.04 & 0.28 & 0.27 & 0.21 & 0.28 & 0.22 & 0.08 & 0.09 & 1.00 & & & & & & & \\
\hline Age (11) & 0.33 & 0.07 & 0.32 & 0.32 & 0.16 & 0.30 & 0.12 & 0.11 & 0.13 & 0.16 & 1.00 & & & & & & \\
\hline Public (12) & -0.02 & -0.02 & 0.01 & 0.01 & -0.10 & -0.03 & -0.01 & 0.00 & 0.02 & 0.04 & -0.04 & 1.00 & & & & & \\
\hline Eastern Europe (13) & -0.34 & -0.05 & -0.43 & -0.49 & -0.61 & -0.50 & -0.54 & 0.02 & 0.02 & -0.06 & -0.03 & 0.26 & 1.00 & & & & \\
\hline Manufacturing (14) & 0.08 & -0.04 & 0.09 & 0.10 & -0.11 & 0.06 & -0.02 & -0.00 & 0.01 & 0.09 & 0.23 & 0.12 & 0.09 & 1.00 & & & \\
\hline Transport (15) & 0.10 & 0.05 & 0.09 & 0.08 & 0.12 & 0.10 & 0.09 & 0.03 & 0.01 & 0.04 & -0.04 & 0.06 & -0.00 & -0.24 & 1.00 & & \\
\hline Finance (16) & 0.07 & 0.02 & -0.06 & -0.08 & 0.09 & -0.01 & -0.01 & 0.02 & 0.03 & 0.01 & 0.00 & -0.26 & -0.12 & -0.23 & -0.10 & 1.00 & \\
\hline Service (17) & -0.06 & -0.00 & -0.04 & -0.10 & -0.08 & -0.03 & -0.06 & -0.01 & -0.01 & -0.01 & -0.04 & 0.07 & 0.08 & -0.37 & -0.16 & -0.15 & 1.00 \\
\hline
\end{tabular}

Source: Authors' computations on Orbis data 